\title{
Correctional Executives' Leadership Self-Efficacy and Their Perceptions of Emotional Intelligence
}

\author{
Donta S. Harper ${ }^{1}$
}

Received: 30 September 2015 / Accepted: 7 December 2015 /

Published online: 14 December 2015

C The Author(s) 2015. This article is published with open access at Springerlink.com

\begin{abstract}
Correctional leadership is virtually an unexamined category, lacking literature regarding what is necessary to be a successful correctional executive. This quantitative study involved examining a leadership model of the relationship between emotional intelligence and leader self-efficacy perceptions among correctional executives and senior-level leaders. A convenience sampling of 112 correctional leaders from across the US participated in the study. Participants were asked to complete the WLEIS (Wong \& Law Emotional Intelligence Scale) and the Leader Efficacy Questionnaire (LEQ). A correlation and Multivariate Analysis of Variance Analyses (MANOVA) were subsequently conducted. The study findings yielded a statistically significant difference among leaders' perceptions of their utilization of emotional intelligence and leader self-efficacy in the work environment. The study findings further suggest that gender is predictive across the instrumentation models for this study, with women exhibiting higher levels of emotional intelligence, self-emotional appraisal, use of emotion, leader self-efficacy, and leader self-regulation efficacy.
\end{abstract}

Keywords Emotional intelligence $\cdot$ Trait emotional intelligence $\cdot$ Emotional quotient . Self-efficacy · Leader self-efficacy · Wong \& law emotional intelligence scale · Leadership self-efficacy questionnaire $\cdot$ Correctional executive $\cdot$ Correctional leadership

The correctional industry, similar to other industries, is facing widespread retirement by "Baby Boomers" who served in key organizational roles and who were vital to strategic outcomes and organizational stability (Stinchomb 2011, Stinchomb et al. 2011; Stinchomb et al. 2009). As the U.S. economy continues to improve, this widespread retirement will adversely impact the corrections industry if corrections is not the field of choice for retaining leaders. The corrections industry therefore needs to remain

Donta S. Harper

dsharper93@gmail.com

1 Argosy University School of Business, Washington State Department of Correction, Division of Community Corrections, Seattle, WA, USA 
competitive in attracting and retaining leaders if the industry is going to have supervisors with sufficient competencies to lead effectively in the C-suite of the organization (Jacobs and Cooperman 2012 Gendreau et al. 2009; Stinchomb 2011, Stinchomb et al. 2011; Stinchomb et al. 2009 Tossi 2012). A competency model is a credible way in which organizations have maintained a strategic and competitive advantage in the marketplace (Sanchez and Levine 2009; Stone et al. 2013). However, professional development is lacking throughout the corrections industry, and no one entity within the corrections industry has sole responsibility for training and developing its entire management core.

To help mitigate this obscurity in training, the National Institute of Corrections (NIC), a small federal agency, provides limited training and offers leadership competencies and technical support to correctional organizations. The NIC has also identified a competency model to train and develop executives and senior-level leaders. However, it does not offer all the necessary training and only offers selective training opportunities to certain leaders based on agency recommendations. The corrections industry is one of the largest criminal justice agencies in the U.S. that lacks a dedicated academy to train its workforce, a workforce consisting of approximately 43,000 correctional leaders including supervisors, managers, senior-level leaders, and executives who are responsible for approximately 474,700 individuals (Jacobs and Cooperman 2012; Maguire and Pastore 2002) and approximately $\$ 39$ billion to $\$ 52.4$ billion in states' correctional budgets (Hendrickson and Delaney, 2012; NASBO 2010-2011). And further compounding the issue of lack of training within the correctional industry, the immense importance of understanding (a) the effectiveness of leadership, (b) the rapidly changing landscape of the correctional environment among its leadership ranks, and (c) the huge responsibility of executives and senior-level leaders has gone virtually understudied (Harper 2014; Jacobs and Cooperman 2012; Walsh 2010).

Gendreau et al. (2009) indicated that correctional leaders need to be content experts who can achieve buy-in, who can resource appropriately to meet the need, and who can rely on scientific literature. The authors asserted that such leaders will be the most successful correctional managers. However, leaders in the corrections industry have not adequately relied on scientific literature that explores two important concepts that impact correctional leadership: self-efficacy and emotional intelligence.

Self-efficacy became notable with the works of Bandura (1986), who linked ability to performance and personal beliefs about specific task capabilities. According to the Bandura (1986) theory of self-efficacy, people formulate their own perceptions of selfefficacy. Bandura (1997) defined self-efficacy as "the beliefs in one's capabilities to organize and execute the courses of action required to produce given attainments" ( $\mathrm{p}$. 3 ). According to the literature, self-efficacy is best assessed through self-reporting (Bandura 1986 Hannah and Avolio 2013 Hannah et al. 2012; Hannah et al. 2008 Khalid and Zubair 2014 McCormick et al. 2002 Ramchunder and Martins 2014 Sarkhosh and Rezaee 2014 Villanueva and Sánchez 2007). Proper assessment of selfefficacy can be the difference between individual and organizational success and failure. Overestimation could lead to organizational problems, setbacks, and loss of confidence for individuals. Underestimation could limit the development and opportunity of potential leaders' opportunity (Tsai et al. 2011).

There is also a subcategory of self-efficacy that is specific to leaders within an organization. According to $\mathrm{Ng}$ et al. (2008), "leadership self-efficacy is a specific form 
of efficacy beliefs related to leadership behaviors, as a key motivational mechanism that links leaders' broad personality traits to leader effectiveness" (p. 73). Leader selfefficacy is a specific domain of exercising leadership that helps provide the ability to set direction for teams, followers, and organizations, by which commitment is gained (Luthans 2002). The belief in one's self to specifically exercise his or her abilities in the contextual environment of leadership is key (Luthans 2002).

In addition to self-efficacy, emotional intelligence is often understudied and underutilized in the corrections industry. Salovey and Mayer (1990) were credited with the formal definition of emotional intelligence, and they revised their definition in 1997. From their work with emotional intelligence, they reasoned that individuals were capable of recognizing emotional information and performing through reasoning to make emotional information useful. Emotional intelligence from this perspective is how well the individual can solve emotional problems (Mayer and Salovey 1997). This approach to understanding the emotional intelligence mental model can be measured through maximum-performance testing (Côté and Miners 2006 Yip and Côté 2012). Salovey and Mayer's model, classified as the ability model, is one of two dominant models in the literature for emotional intelligence (Ciarrochi et al. 2000 Furnham 2012 Mayer et al. 2000 Pérez et al. 2005 Villanueva and Sánchez 2007 Yip and Côté 2012).

The second dominant model is the trait emotional intelligence model (Pérez et al. 2005 Villanueva and Sánchez 2007 Yip and Côté 2012). The trait emotional intelligence premise relates to individual behavioral dispositions and self-perceived abilities to sense, understand, and effectively apply the power of emotions as a source of human energy, information, knowledge, connection, and influence that can only be best assessed by self-reporting. These individual/executive predictable skills utilized in the organizational environment impact individuals and groups of individuals in organizations in effective ways (Akinboye 2003 Fazio 2010; Weisinger 1998 Wong and Law 2002; Law et al. 2004).

These two psychological constructs, emotional intelligence and leader self-efficacy, constitute the theoretical focus of this study. The study involved utilizing a systematic identification for assessing leadership competencies (McClelland 1973). Empirical evidence indicates that emotional intelligence skill can be associated with predictive occupational effectiveness. Therefore the following hypotheses are proposed:

H1 - There is an overall positive relationship between correctional executives' sense of leader self-efficacy and their emotional intelligence perceptions.

$\mathrm{H} 2$ - There is predictability of a positive relationship in correctional executives' sense of leader self-efficacy and emotional intelligence subscales based on their perceptions.

Bandura's (1997) study supports the research hypotheses. Bandura argued that the critical components for emotional intelligence-self-awareness, self-regulation, and control of others' emotions - are part of the development of self-efficacy perceptions. Additionally, Ramchunder and Martins (2014) conducted a self-efficacy, emotional intelligence, and leadership style study on policemen in South Africa. In their study findings, self-efficacy was correlated with perceptions of emotional intelligence $(r=0.436, p<0.01)$, supporting the notation of a positive relationship between the two constructs emotional intelligence and self-efficacy. Moreover, Sarkhosh and Rezaee (2014) conducted a study on teachers' emotional intelligence and self-efficacy beliefs. Similar to executives in corrections, teachers 
work in complex environments, have a lot of personalities to manage, and are tone setters through their efforts. In their findings, a strong relationship existed between teachers' selfefficacy and emotional intelligence perceptions $(r=0.531, p<.05)$.

Although Ramchunder and Martins (2014) studied policemen in South Africa and Sarkhosh and Rezaee (2014) studied teachers, there is an absence of research investigating the link between emotional intelligence and leader self-efficacy for correctional leaders in the United States. Research investigating emotional intelligence and leader self-efficacy would be relevant in the corrections industry for several reasons. Traditionally, corrections has been unique due to its own structural and culture facets (Jacobs and Cooperman 2012). Research provides better understanding of the impacts of emotional intelligence and leader self-efficacy on executive leaders, who are viewed as most influential in the areas of organizational outcomes and organizational culture. In addition, research can help correctional leaders by uncovering whether or not present and future correctional leaders should be trained in the areas of identifying and improving their emotional intelligence and self-efficacy to become better leaders. The need for this study arose in part due to this gap in research for the corrections industry.

Following the assertion that self-efficacy can be an accelerant for leadership development (Hannah et al. 2012, Hannah et al. 2008), the purpose of this study was to ascertain if a statistically significant relationship between emotional intelligence and leader self-efficacy exists. To accomplish this, the psychological constructs, skills, and abilities that positively contribute to organizational performance were examined by correlating emotional intelligence and leader self-efficacy through surveying correctional leaders' perceptions of their own emotional intelligence and leader self-efficacy.

\section{Research Design}

\section{Research Procedure}

The sample represented correctional executives and senior-level leaders from across the US. To fit the criteria for this study, participants had to fit into two categories of leadership as determined by their parent organization. The NIC describes executives as the head of the organization and utilizes titles such as CEO, director, commissioner, secretary, and executive director (Campbell 2006; NIC, http//nicic.gov/, 2015). The NIC describes senior-level leaders as elected or appointed by the organizational head. The position can be classified or exempt and serves at the pleasure of the jurisdiction's elected official(s). Senior-level leaders are advisors to the director in policy development, and they interpret policy within the parameters the executive sets. Senior-level leaders are within the upper third of the organizational structure (Campbell 2006; NIC, $\mathrm{http} / /$ nicic.gov/, 2015). Convenience sampling based on availability was employed in this study (Leedy and Ormrod 2010). Correctional executives and senior-level leaders were targeted through professional associations for executives and through direct communication surveys sent to the agency email addresses that were found and to the worldwide web names whose position title was either correctional executive or correctional senior-level leader. The professional associations contacted were American Correctional Association, Association of State Correctional Administrators, National Association of Probation Executives, Chief Probation Officer Associations, Sheriffs 
Associations, and National Organization of Black Law Enforcement Executives. A survey instrument was sent via email by the SurveyMonkey® link to study participants consisting of executives and senior-level leaders, professional associations, listserv, and professional and trade organizations for corrections. Participation from this hard to reach population was achieved through research snowball sampling (Biernacki and Waldorf 1981; Faugier and Sargeant 1997). The survey sent included an informed consent form and a form outlining conditions of confidentiality. The survey was open from June 25, 2015 to September 1, 2015. Prior to study commencement, permission from the instrumentation authors for the purpose of this study was granted in March 2015 to utilize the WLEIS and LEQ. The LEQ is copyrighted by its authors.

\section{Participants}

One hundred and twelve study participants returned usable, completed surveys. Participants represented five U.S. regions: 15 were from the Northeast (13\%), 33 were from the Midwest (30\%), 13 were from the Southwest (12\%), 16 were from the Southeast (14\%), 34 were from the West (30\%), and 1 gave no response. Participants consisted of 47 executives (42\%) and 65 senior-level leaders (58\%). Sixty-six (59\%) identified as males, 44 identified as females (39\%), 1 preferred not to identify, and 1 gave no response. The racial/ethnic make-up consisted of 2 Asian/Pacific Islander (1.8\%), the smallest represented group. White/Caucasian represented the largest group, with 92 participants (82\% of the sample). For the remaining groups, 8 marked Black/African American (7\%), 6 marked Hispanic/Latino (5\%), 3 preferred not to answer (3\%), and 1 gave no response. Regarding education levels, 52 marked their highest level of education as a bachelor's degree (46\%), 45 marked Master's degree (40\%), 5 marked doctorate (4\%), 1 marked Associate's degree (.9\%), 6 marked that they had 15 or more college credits (5\%), and 3 marked high school or GED $3(3 \%)$. For the years of experience categories, 24 marked 2 to 3 years of executive experience $(21 \%)$, and 24 marked 7 to 9 years of executive experience $(21 \%)$, the largest groups represented. Sixteen marked 4 to 6 years of executive experience (14\%), 14 marked 10 to 12 years of executive experience (13\%), 22 marked 13 to 15 years of executive experience (20\%), and 12 participants marked one year or less (11\%), the smallest group represented.

\section{Measures}

The WLEIS is a measure for organizational emotional intelligence, agency commitment, and organizational performance. Its authors claim its validity is related to job performance and satisfaction, organizational commitment, and turnover intention (Pérez et al. 2005; Wong and Law 2002). Utilizing this trait emotional intelligence measure, the present study is expected to correlate well with another typicalperformance measure, which is a non-cognitive measure (Jensen et al. 2007; Mavroveli et al. 2009). The WLEIS is a 16-item, 4-part dimensions subscales ([a] self-emotion appraisal, or SEA, [b] emotional appraisal, or OEA, [c] use of emotion, or UOE, and [d] regulation of emotion, or ROE) measured using a 7-point Likert scale. The internal consistencies for this present study for respondents of this sample were in the acceptable range (George and Mallery 2003). Specifically, Cronbach's alpha was .90 for the overall measure, .82 for SEA, .90 for OEA, .84 for UOE, and .86 for ROE. 
This present study also involved the LEQ (Hannah and Avolio 2013), one of a few scales that solely measures leadership self-efficacy in an organization environment (Hannah and Avolio 2013). Empirical research on the LEQ has validated three components. Authors indicate the LEQ has been validated across seven diverse sample groups and has shown to predict outcomes related to leader performance, enhanced motivation to lead others, and highly effective leadership style, such as transformational leadership (Hannah and Avolio 2013). The LEQ is a 22-item assessment with 3 subscales: (a) leader action self-efficacy (LAE), (b) leader self-regulation efficacy (LSRE), and (c) leader means efficacy (LME). It consists of a 10-point Likert scale with 10 increments from 0 not at all confident to 100 totally confident. The LEQ can be used as a self-reporting measure to assess leaders' perceptions of their own confidence and capabilities (Hannah and Avolio 2013). The internal consistencies for this study for respondents of this sample were in the acceptable range (Hannah and Avolio 2013). Specifically, Cronbach's alpha was .92 for the overall measure, .91 for LAE, .93 for LRSE, and .83 for LME.

\section{Data Analysis}

Descriptive statistics and inferential statistics were calculated utilizing the SPSS statistical package, version 23. In this study, Cronbach's alpha was conducted and provides details regarding the reliability of the measures. A nonparametric test, Spearman's rho, was used to test the relationship between the emotional intelligence and leader selfefficacy of executives. The LEQ was used to investigate which factors of the WLEIS have more power in predicting leaders' self-efficacy. Finally, this study also involved conducting a MANOVA test with appropriate ANOVA testing.

\section{Results}

In this study, the confidence interval was $95 \%$, and the significance level was .05 . Table 1 provides a summary of the two instruments utilized in this study, the WLEIS and LEQ, in descriptive statistics. The emotional intelligence scale had a mean of 81.21, a mode of 80, and a standard deviation of 7.84. The LEQ had a mean of 175.36 , a mode of 188.00 , and a standard deviation of 22.85 .

As a test for normality of the data, a Shapiro-Wilks' statistical test was conducted to determine the normal distribution of instrument variables, as indicated in Table 2. Shapiro-Wilks' is a test of normality for scales and subscales, and the data provided

Table 1 WLEIS and LEQ Descriptive Statistics

\begin{tabular}{llll}
\hline & WEIS Total & \multicolumn{2}{l}{ Leader-Self Questionnaire Total } \\
\hline $\mathrm{N} \quad$ Valid & 104 & 104 \\
& Missing & 8 & 8 \\
Mean & 81.21 & 175.36 \\
Mode & 80.00 & 188.00 \\
Std. Deviation & 7.84 & 22.85 \\
Cronbach's alpha & .90 & .92 \\
\hline
\end{tabular}


from the overall instrumentations indicates a $p$-value of less than 0.05 and therefore is not normally distributed. This result supports the utilization of non-parametric correlation testing, for which Spearman's rho test was used.

To investigate the relationship between the executives' perceptions, a Spearman's rho correlation was conducted. The results indicate a statistically significant correlation between emotional intelligence and leader self-efficacy $(r=.449, p<.05$; Table 3$)$, in this case a moderate correlation according to Cohen et al. (2007).

Table 4 further displays the correlations between leaders' perceptions with a Spearman's rho at the instruments' subscale levels for the WLEIS's 16 items and the LEQ's 22 items. The analysis indicates that several items significantly correlate. The WLEIS SEA, UOE, and ROE dimensions and the LEQ LME component do not correlate among variables SEA $r=.187, p=.058$, UOE $r=.155, p=.115$ and ROE $r=.185, p=.058$. All other dimensions of the WLEIS and LEQ indicate significant correlation and therefore further support hypothesis 1, a positive relationship among emotional intelligence and leader self-efficacy.

To test hypothesis 2, an MANOVA was conducted to examine four leader characteristics identified as independent variables by utilizing dependent variables of the WLEIS four dimensions and LEQ three components (see table 5). The independent variables were leaders' (a) role in the organization, (b) gender, (c) ethnicity, and (d) length of services in an executive role. There were significant differences between males and females among the dimensions of emotional intelligence. In SEA, females had a higher mean score $(M=21.548)$ than the males $(M=20.950)$ did, in UOE females had a higher mean score $(M=21.238)$ than the males $(M=20.500)$ did, in OEA females had a higher mean score $(M=19.643)$ than the males $(M=18.900)$ did, and in ROE, females had a slightly lower mean score $(M=20.214)$ than the males $(M=20.483)$ did (see Table 6). There was also a significant difference between males and females on the LEQ subcomponent LRSE. Females had a substantially higher mean score $(M=69.625)$, than males $(M=67.742$; see Table 7$)$. As follow-up, an ANOVA test was conducted to examine the association between dependent and independent variables at the multivariate effect for the variables SEA, UOE, ROE, OEA, LAE, LME, and LSRE by gender. These findings support hypothesis 2, retaining the alternative hypothesis that there is predictability of a positive relationship with

Table 2 Tests of normality Shapiro-Wilks' for scale and subscale

\begin{tabular}{llll}
\hline & \multicolumn{3}{l}{ Shapiro-Wilk } \\
\cline { 2 - 4 } & Statistic & $d f$ & Sig. \\
\hline Leader Self Questionnaire Total & .924 & 96 & .000 \\
WLEIS Total & .934 & 96 & .000 \\
Subscale LAE & .921 & 96 & .000 \\
Subscale LME & .924 & 96 & .000 \\
Subscale LSRE & .897 & 96 & .000 \\
Subscale SEA & .898 & 96 & .000 \\
Subscale OEA & .844 & 96 & .000 \\
Subscale UOE & .922 & 96 & .000 \\
Subscale ROE & .937 & 96 & .000 \\
\hline
\end{tabular}


Table 3 Spearman's Rho Correlation between constructs EI and LEQ

\begin{tabular}{lllll}
\hline & & $\begin{array}{l}\text { Leader Self } \\
\text { Questionnaire } \\
\text { Total }\end{array}$ & WEIS Total \\
\hline Spearman's rho & $\begin{array}{c}\text { Leader Self Questionnaire } \\
\text { Total }\end{array}$ & Correlation Coefficient & 1.000 & $.449^{* *}$ \\
& Sig. (2-tailed) &. & .000 \\
& $\mathrm{~N}$ & 104 & 96 \\
& Correlation Coefficient & $.449^{* *}$ & 1.000 \\
& Sig. (2-tailed) & .000 &. \\
& $\mathrm{~N}$ & 96 & 104 \\
\hline
\end{tabular}

** indicates Correlation is significant at the 0.01 level (2-tailed)

corrections leaders' sense of use of leader (SEA) self-emotional appraisal, (UOE) use of emotion, and (LRSE) leader self-regulation efficacy was predictable at the significant level $p<.025$.

\section{Discussion}

The aim of the study was to examine the psychological constructs of emotional intelligence and leader self-efficacy to determine the effects of a relationship conjectured to contribute to successful organizational performance. Results indicate a statistically significant relationship between the constructs, meaning the skills identified are useful in the correctional environment based on the leaders' own perceptions. The findings are consistent with the findings of Ramchunder and Martins (2014), who correlated police leadership with perceptions of emotional intelligence and self-efficacy. The findings are also consistent with the findings of Sarkhosh and Rezaee (2014), who positively correlated teachers' emotional intelligence and self-efficacy beliefs. Hypothesis 1 alternative was retained.

The study findings, however, did not support any relationship between three dimensions of the WLEIS correlating with the LEQ single component LME. The first WLEIS dimension, SEA, assesses individuals'ability to understand and express their own emotions. An example item is, "I really understand what I feel". The second WLEIS dimension, UOE, assesses individuals' ability to direct their emotions towards constructive activities and personal performance. An example item is, "I always tell myself that I am competent". The third dimension, ROE, assesses individuals' ability to evaluate their emotions, facilitating rapid change and success in psychological distress. An example item is, "I am able to control my temper and handle difficulties". The LME component of the LEQ assesses individuals' ability to draw from resources in the work environment to leverage their leadership impact. An example item is, "as a leader I can rely on the organization to provide the resources needed to be effective". In a study that Kafetsios et al. (2011) conducted between education directors and educators' subordinates, they found a negative correlation among SEA, UOE, and ROE utilizing the WLEIS. They indicated that consistency with self-appraisal skills may lead to negative 


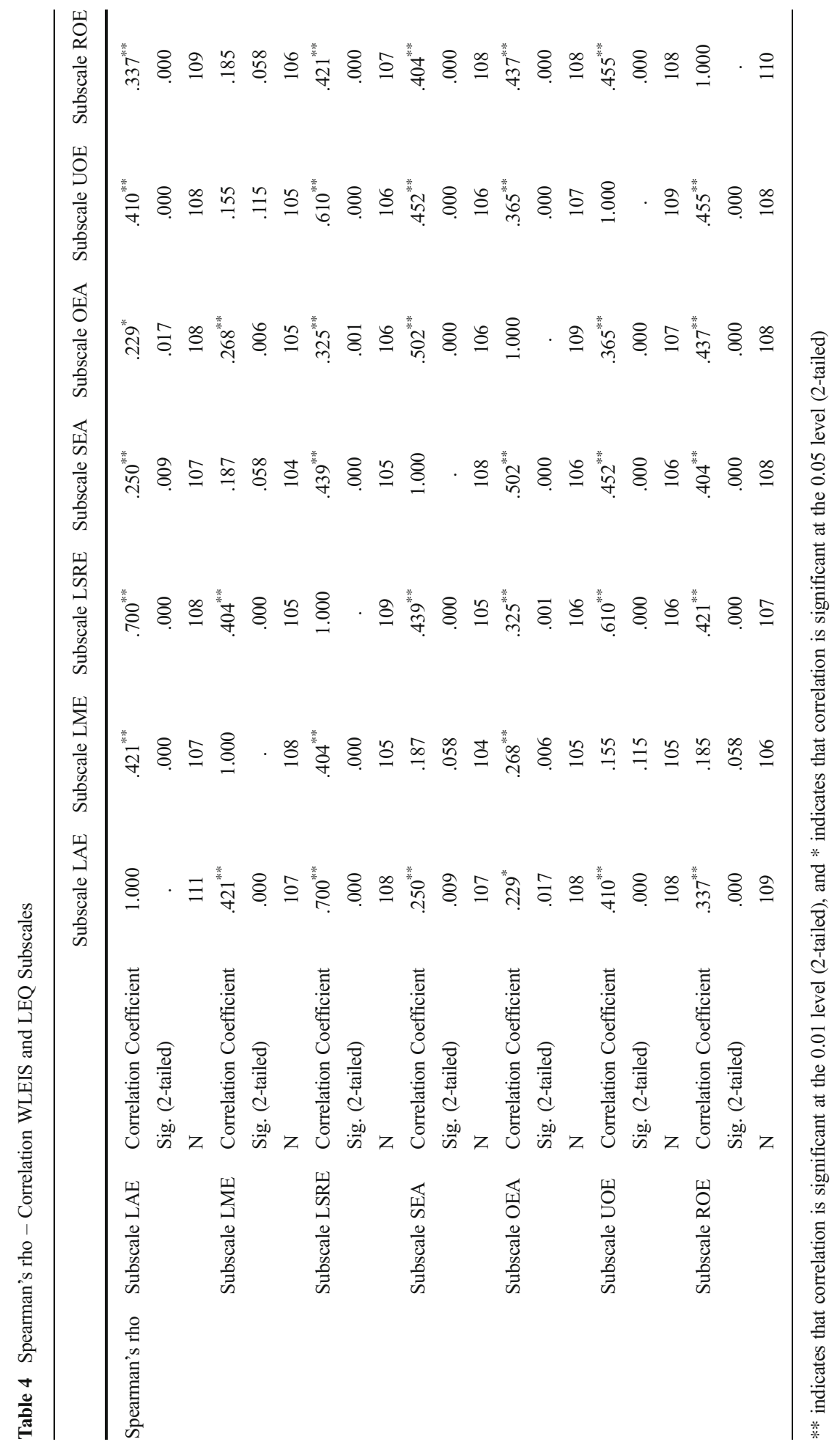




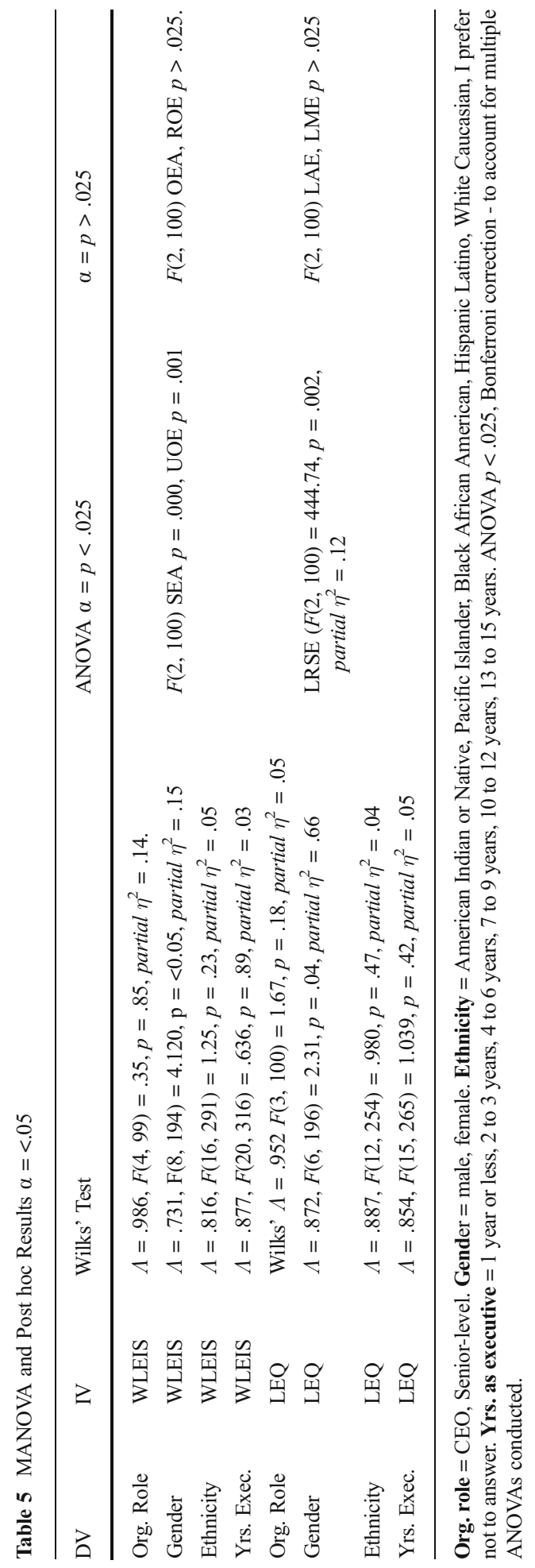


Table 6 WLEIS Significant Univariate Effects for Gender group (at <.001)

\begin{tabular}{|c|c|c|c|c|c|c|c|c|}
\hline \multirow{2}{*}{$\begin{array}{l}\text { Dependent } \\
\text { Variable }\end{array}$} & \multirow[t]{2}{*}{ Gender } & \multirow[t]{2}{*}{ Mean } & \multirow{2}{*}{$\begin{array}{l}\text { Std. } \\
\text { Error }\end{array}$} & \multicolumn{2}{|c|}{$95 \%$ Confidence Interval } & \multirow[t]{2}{*}{$\mathrm{F}$} & \multicolumn{2}{|c|}{$d f d$} \\
\hline & & & & $\begin{array}{l}\text { Lower } \\
\text { Bound }\end{array}$ & $\begin{array}{l}\text { Upper } \\
\text { Bound }\end{array}$ & & & \\
\hline \multirow[t]{3}{*}{ SEA Dimension } & Male & 20.950 & .261 & 20.433 & 21.467 & 11.365 & 2 & 100 \\
\hline & Female & 21.548 & .311 & 20.930 & 22.165 & & & \\
\hline & $\begin{array}{l}\text { I prefer not to } \\
\text { identify }\end{array}$ & 12.000 & 2.018 & 7.996 & 16.004 & & & \\
\hline \multirow[t]{3}{*}{ OEA Dimension } & Male & 18.900 & .421 & 18.066 & 19.734 & 3.066 & 2 & 100 \\
\hline & Female & 19.643 & .503 & 18.646 & 20.640 & & & \\
\hline & $\begin{array}{l}\text { I prefer not to } \\
\text { identify }\end{array}$ & 12.000 & 3.257 & 5.537 & 18.463 & & & \\
\hline \multirow[t]{3}{*}{ UOE Dimension } & Male & 20.500 & .305 & 19.896 & 21.104 & 8.104 & 2 & 100 \\
\hline & Female & 21.238 & .364 & 20.516 & 21.960 & & & \\
\hline & $\begin{array}{l}\text { I prefer not to } \\
\text { identify }\end{array}$ & 12.000 & 2.359 & 7.319 & 16.681 & & & \\
\hline \multirow[t]{3}{*}{ ROE Dimension } & Male & 20.483 & .278 & 19.933 & 21.034 & 7.706 & 2 & 100 \\
\hline & Female & 20.214 & .332 & 19.556 & 20.872 & & & \\
\hline & $\begin{array}{l}\text { I prefer not to } \\
\text { identify }\end{array}$ & 12.000 & 2.150 & 7.735 & 16.265 & & & \\
\hline
\end{tabular}

outcomes for subordinates. Individuals who are self-aware of their emotions may be seen as manipulative or insincere, perhaps seen as too much in control. In the present study, subordinates' perceptions were not captured; only leaders' perceptions were captured. Findings may suggest that leaders perceive they are in control of their emotions and

Table 7 LEQ Significant Univariate Effects for Gender group (at <.001)

\begin{tabular}{|c|c|c|c|c|c|c|c|c|}
\hline \multirow{2}{*}{$\begin{array}{l}\text { Dependent } \\
\text { Variable }\end{array}$} & \multirow[t]{2}{*}{ Gender } & \multirow[t]{2}{*}{ Mean } & \multirow[t]{2}{*}{ Std. Error } & \multicolumn{2}{|c|}{$95 \%$ Confidence Interval } & \multirow[t]{2}{*}{$\mathrm{F}$} & \multirow[t]{2}{*}{$d f$} & \multirow[t]{2}{*}{ df error } \\
\hline & & & & Lower Bound & Upper Bound & & & \\
\hline \multirow[t]{3}{*}{ LAE Comp. } & Male & 55.532 & .999 & 20.433 & 53.550 & 3.371 & 2 & 100 \\
\hline & Female & 55.525 & 1.244 & 20.930 & 53.057 & & & \\
\hline & $\begin{array}{l}\text { I prefer not to } \\
\text { identify }\end{array}$ & 35.000 & 7.869 & 7.996 & 19.389 & & & \\
\hline \multirow[t]{3}{*}{ LME Comp. } & Male & 51.968 & 1.371 & 18.066 & 49.248 & 1.381 & 2 & 100 \\
\hline & Female & 52.950 & 1.706 & 18.646 & 49.564 & & & \\
\hline & $\begin{array}{l}\text { I prefer not to } \\
\text { identify }\end{array}$ & 35.000 & 10.793 & 5.537 & 13.588 & & & \\
\hline \multirow[t]{3}{*}{ LSRE Comp. } & Male & 67.742 & 1.048 & 19.896 & 65.662 & 6.528 & 2 & 100 \\
\hline & Female & 69.625 & 1.305 & 20.516 & 67.036 & & & \\
\hline & $\begin{array}{l}\text { I prefer not to } \\
\text { identify }\end{array}$ & 40.000 & 8.254 & 7.319 & 23.624 & & & \\
\hline
\end{tabular}


organizations (the sample population represents the upper 3rd of their organizations). They might feel less urgency to leverage their leadership impact if their behavior could be viewed negatively among subordinates. Further study would be needed to understand if this is true, to understand why LME frequently does not correlate, and to understand how this impacts leaders' development. If Kafetsios et al.'s findings relate to the present study, leaders might not want to appear as being manipulative, insincere, or controlling when providing leadership in their work environments.

Finally, results indicate gender might influence the level of emotional intelligence that female leaders use in the work environment. Women correctional executives displayed a higher level of emotional intelligence than men did in three of four WLEIS dimensions, SEA, OEA and UOE. However, female leaders did have a moderately lower ROE mean than their male counterparts did, resulting in retaining hypothesis 2 . Leader self-regulation also provided support for hypothesis 2; MANOVA and ANOVA testing indicated gender as a key factor. Female leaders had substantially higher levels of leader self-regulation efficacy than men did. According to Hannah and Avolio (2013), these leaders have a "perceived capability to a) think through complex leadership situations, interpret their followers and the context and generate novel effective solutions to leadership problems; coupled with b) [an] ability to motivate oneself to enact those solutions" (p. 6). These findings suggesting that gender might be a gauge for predicting higher levels of emotional intelligence are similar to the study findings of Siegling et al. (2014) for trait emotional intelligence or self-efficacy among leaders and non-leaders. The leaders for Siegling et al.'s (2014) study were also identified as based on occupational position, and the women in that study had higher levels of emotional intelligence than the men did when accounting for study effect size.

The study findings have specific implications for the corrections industry. The NIC has identified a competency model to train and develop executives and senior-level leaders. The study findings indicate that developing emotional intelligence and selfefficacy should constitute a significant part of this competency model to train correctional executives and senior-level leaders. Leaders who are able to understand the needs of followers and who are able to provide constructive feedback to followers are more likely to experience success than those who do not. The study provides a profile of traits and characteristics utilized in the correctional work environment that are associated with success, and emotional intelligence and self-efficacy lie at the center of these traits. Accordingly, the NIC competency model should include training in those two areas. Additionally, the findings also suggest that there are gender differences in the corrections industry. Women correctional executives displayed a higher level of emotional intelligence than men did in three of four WLEIS dimensions. Despite this, women continue to be underrepresented in leadership roles in the corrections industry. Warner (2014) reported that women constitute $51 \%$ of the U.S. population and $52 \%$ of the U.S. labor force. However, women constitute only $15 \%$ of executive officers. The study findings should warrant great opportunity to ascend to leadership positions in the corrections industry for women who have the skill sets that the NIC has identified as necessary for leading in the C-suite of the organization. As a result, the study findings suggest that men and women in the corrections industry should be provided equal training and development access as well as equal opportunity to ascend to leadership positions. This has implications for hiring consultants to assess both male and female potential candidates for executive roles who possess the desired skills and characteristics. 
The findings in the present study along with the findings from previous studies present the opportunity for continued study on emotional intelligence and self-efficacy in different environments. Further research could also lead to development of a single instrument for measuring emotional intelligence and leader self-efficacy at the organizational and individual levels to assess skills and abilities for skill development. In addition, necessity for further research into these topics arises in part due to this study's limitations. This study is limited by its sole industry focus on corrections and correctional executives. Cross sectional studies have been limited due to broad work differences among studied samples and no clear distinction of which differences are impactful (Palaiou and Furnham 2014). Although this study certainly has value for the corrections industry, assumptions that emotional intelligence and self-efficacy correlate to strong leadership in other industries might not prove true due to the uniqueness of the corrections industry. This study is also limited by its sample size; a larger sample size might reveal more or different data. The convenience and snowballing sample methods held great value for selecting participants who met the study requirements, but simple random sampling of all correctional executives and senior-level leaders across a large number of correctional organizations throughout the country would be the best way to survey the number of participants that would make the results of this study generalizable. However, despite these limitations, the study findings do provide a step in the right direction towards understanding the impacts of emotional intelligence and selfefficacy on the leadership of correctional executives and senior-level leaders.

Open Access This article is distributed under the terms of the Creative Commons Attribution 4.0 International License (http://creativecommons.org/licenses/by/4.0/), which permits unrestricted use, distribution, and reproduction in any medium, provided you give appropriate credit to the original author(s) and the source, provide a link to the Creative Commons license, and indicate if changes were made.

\section{References}

Akinboye, J. O. (2003). Creativity, innovation, and success. Ibadan, Nigeria: Sterling Horde Publishers Ltd.. Bandura, A. (1986). Social foundations of thought and action: A social cognitive theory. NJ Prentice Hall: Englewood Cliffs.

Bandura, A. (1997). Self-efficacy: The exercise of control. New York: Freeman and Company.

Biernacki, P., \& Waldorf, D. (1981). Snowball sampling: Problems and techniques of chain referral sampling. Sociological Methods \& Research, 10(2), 141-163.

Campbell, N. (2006). National Institute of Corrections, Correctional Leadership Competences for 21st Century Executive and Senior-Levels. NIC: US Department of Justice Retrieved from: www.nicic.org.

Ciarrochi, J., Chan, A. Y. C., \& Caputi, P. (2000). A critical evaluation of the emotional intelligence construct. Personality and Individual Differences, 28, 539-561.

Cohen, L., Manion, L., \& Morrison, K. (2007). Research methods in education (6th ed., ). New York: Routledge.

Côté, S., \& Miners, C. T. H. (2006). Emotional intelligence, cognitive intelligence, and job performance. Administrative Science Quarterly, 51, 1-28.

Faugier, J., \& Sargeant, M. (1997). Sampling hard to reach populations. Journal of Advanced Nursing, 26, 790-797.

Fazio, R. (2010). Using executive emotional intelligence (EEI) for leadership success. Retrieved from: www. amanet.org/training/articles/using-executive-emotional-intelligence

Furnham, A. (2012). Emotional intelligence. Research Department of Clinical: Educational and Health Psychology University College UK. 
Gendreau, P., Smith, P., \& Theriault (2009). Chaos theory and correctional treatment common sense, correctional quackery, and the law of fartcatchers. Journal of Contemporary Criminal Justice, 25(4), 384-396.

George, D. \& Mallery, M. (2003). Using SPSS for step by step: A simple guide and reference. Boston, MA: Allyn Bacon

Hannah, S.,. T., \& Avolio, B. J. (2013). Leader Efficacy Questionnaire. Inc: Published by Mind Garden.

Hannah, S.,. T., Avolio, B. J., Luthans, F., \& Harms, P. (2008). Leadership efficacy: Review and future direction. Leadership Quarterly, 19, 669-692.

Hannah, S.,. T., Avolio, B. J., Walumbwa, F. O., \& Chan, A. (2012). Leader self and means efficacy: A multicomponent approach. Organizational behavior and human decision process, 118, 143-161.

Harper, D. S. (2014). An examination and analysis of career pathways and leadership competencies of correctional executives and senior-level leaders. Doctoral Dissertation Research in partial fulfillment of requirements for Degree Argosy University

Hendrickson, C. \& Delaney, R. (2012). The price of prisons: What incarceration cost taxpayers. Vera Institute of Justice, Center on Sentencing and Corrections

Jacobs, J. B., \& Cooperman, K. T. (2012). A proposed national correction college. New York University of Law and Legal Theory Working Papers.

Jensen, S., Kohn, C., Rilea, S., Hannon, R., \& Howells, G. (2007). Emotional intelligence a literature review. University of the Pacific Department of Psychology.

Kafetsios, K., Nezlek, J.,. B., \& Vassiou, A. (2011). A multilevel analysis of relationships between leaders' and subordinates emotional intelligence and emotional outcomes. Journal of Applied Social Psychology, 41(5), 1121-1144.

Khalid, S., \& Zubair, A. (2014). Emotional intelligence, self-efficacy, and creativity among employees of advertising agencies. Pakistan Journal of Psychological Research, 29(2), 203-221.

Law, K. S., Wong, C. S., \& Song, L. J. (2004). The construct and criterion validity of emotional intelligence and its potential utility for management studies. Journal of Applied Psychology, 89(3), 483-496.

Leedy, P. D., \& Ormrod, J. E. (2010). Practical research: Planning and design (9th ed., ). Upper Saddle River, NJ: Prentice Hall.

Luthans, F. (2002). The need for and meaning of positive organizational behavior. Journal of Organizational Behavior, 23(6), 695-706.

Maguire, K. \& Pastore, A. L. (Eds.). (2002). Sourcebook of criminal justice statistics, 2000. Hindelang Criminal Justice Research Center

Mavroveli, S., Petrides, K. V., Sangareau, Y., \& Furnham, A. (2009). Exploring the relationship between trait emotional intelligence and objective socio-emotional outcomes in childhood. British Journal of Educational Psychology, 79, 259-272.

Mayer, J.,. D., \& Salovey, P. (1997). What is emotional intelligence? In P. Salovey, \& D. Sluyter (Eds.), Emotional Development and Emotional Intelligence: Implications for Educators (pp. 3-31). New York: Basic Books.

Mayer, J. D., Salovey, P., \& Caruso, D. R. (2000). Emotional intelligence as zeitgeist, as personality, and as intelligence. In R. Bar-On, \& J. D. A. Parker (Eds.), Handbook of emotional intelligence (pp. 92-117). New York: Jossey-Bass.

McClelland, D. C. (1973). Testing for competence rather than intelligence. American Psychologist, 28(1), 1-14.

McCormick, M. J., Tanguma, J., \& Lopez-Foment, A. S. (2002). Extending self-efficacy theory of leadership: A review and empirical test. Journal of Education, 1(2), 34- 49.

NASBO. State Expenditure Report, 2010-2011. Fiscal 1986 marks the first year that corrections data in NASBO's annual State Expenditure Report is complete.

Ng, K. Y., Ang, S., \& Chan, K. Y. (2008). Personality and leader effectiveness: A moderated mediation model of leadership self-efficacy, job demands and autonomy. Journal of Applied Psychology, 93(4), 733-743.

Nicic.gov/, (2015). National Institute of Corrections, website. Retrieved from: http//nicic.gov/, 2015

Palaiou, K., \& Furnham, A. (2014). Are bosses unique? Personality facet differences between CEOs and staff in five work sectors. Consulting Psychology Journal: Practice and Research, 3(66), 173-196.

Pérez, J. C., Petrides, K. V., \& Furnham, A. (2005). Measuring trait emotional intelligence. In R. Schulze, \& R. D. Roberts (Eds.), International handbook of emotional intelligence (pp. 181-201). Cambridge, MA: Hogrefe \& Huber.

Ramchunder, Y. \& Martins, N. (2014). The role of self-efficacy, emotional intelligence and leadership style as attributes of leadership effectiveness. SA Journal of Industrial Psychology/SA Tydsrif vir Bedryfsielkunde, 40(1), Art., \#1100, 11 pages. doi:10.4101/sajipp.v40i1100 
Salovey, P., \& Mayer, J. D. (1990). Emotional intelligence. Imagination, Cognition, and Personality, 9, 185-211.

Sanchez, J. I., \& Levine, E. L. (2009). What is (or should be) the difference between competency modeling and traditional job analysis? Human Resource Management Review, 19, 53-63.

Sarkhosh, M., \& Rezaee, A. A. (2014). How does university teachers' emotional intelligence relate to selfefficacy beliefs? Iran: University of Tehran.

Siegling, A. B., Nielsen, C., \& Petrides, K., V. (2014). Trait emotional intelligence and leadership in a European multinational company. Personality and Individual Differences, 65(2014), pp. 65-68.

Stinchomb, J. B. (2011). The upcoming tsunami: Core leadership competences. American Jails: May/Jun, 25(2), 17-24.

Stinchomb, J. B., McCampbell, S. W., \& Leip, L. (2009). The future is now: Recruiting, retaining, and developing the 21st century workforce. Washington, DC: US Department of Justice, Bureau of Justice Assistance.

Stinchomb, J. B., Smith, C. J., McCampbell, S. W. \& Macini, C. (2011). National jail succession planning and leadership development project: Identifying core competences and required knowledge, skills, and abilities (KSAs) for jail leaders' method and outcomes. The center for Innovative Public Policy

Stone, T. H., Webster, B. D., \& Schoonever, S. (2013). What do we know about competency models? International Journal of Selection and Assessment, 21(3), 334-338.

Tossi, M. (2012). Employment outlook: 2010-2020 labor force projections to 2020: A more slowly growing workforce. Labor force. Projections, Bureau of Labor Statistics

Tsai, M.-T., Tsai, C.-L., \& Wang, Y.-C. (2011). A study on the relationship between leadership style, emotional intelligence, self-efficacy and organizational commitment: A case study of the banking industry in Taiwan. African Journal of Business Management, 5(13), 5319-5329.

Villanueva, J. J., \& Sánchez, J. C. (2007). Trait emotional intelligence and leadership self-lefficacy: Their relationship with collective efficacy. The Spanish Journal of Psychology, 10(2), 349-357.

Walsh, F. (2010). The Development of Comprehensive Criminal Justice Leadership Standards: A Modified Delphi Study Approach - Dissertation. University of Phoenix

Warner, J. (2014). The women's leadership gap. Center for American Progress

Weisinger, H. (1998). Emotional intelligence at work: The untapped edge for success. San Francisco: JosseyBass

Wong, C., \& Law, K. S. (2002). The effects of leader and follower emotional intelligence on performance and attitude: An exploratory study. The Leadership Quarterly, 13, 243-274.

Yip, J. A., \& Côté, S. (2012). The emotionally intelligent decision maker: Emotion-understanding ability reduces the effect of incidental anxiety and risk taking. Psychology Science, $X X(\mathrm{X}), 1-8$.

Donta S. Harper is graduate from Argosy University. He currently works as a Senior Administrator in Washington with responsibility for Community Operations. 